\title{
Challenging UN Security Council- and InTernational Criminal Court-Requested Asset Freezes in Domestic Courts: Views From the United Kingdom and ItALY
}

\author{
Daley J Birkett* and Dini Sejko**
}

First published online on 8 February 2022

This article analyses attempts by the Libyan Investment Authority (LIA), the sovereign wealth fund of Libya, to challenge the domestic implementation of asset-freezing measures requested by the United Nations Security Council (UNSC) and the International Criminal Court (ICC) in the United Kingdom (UK) and Italy. The UNSC requested that states freeze LIA assets in early 2011 before partially easing the restrictions imposed in September of the same year, while the ICC requested the freezing of assets belonging to the then Libyan leader, Muammar Gaddafi, and two further accused persons shortly thereafter. The article scrutinises how these measures were incorporated into the legal orders of the UK and Italy before analysing how the LIA has challenged these actions in the Italian courts and those of England and Wales. In so doing, it aims to demonstrate that domestic courts offer additional fora in which individuals (and entities) might seek to enforce the legal protection to which they are entitled when faced with their assets having been frozen by states at the request of the UNSC and/or the ICC.

Keywords: United Nations Security Council (UNSC) targeted sanctions, International Criminal Court (ICC), asset freeze, sovereign wealth funds, Libya

\section{INTRODUCTION}

In early 2011, responding to the outbreak of the Libyan civil war, the United Nations Security Council (UNSC) requested UN member states to freeze the assets of Muammar Gaddafi and five members of his immediate family. ${ }^{1}$ Less than one month later, the UNSC adopted further measures, expanding the freeze to cover the assets of the Libyan Investment Authority (LIA), Libya's sovereign wealth fund (SWF), among other individuals and entities. ${ }^{2}$ The freeze was, in turn, implemented in the domestic legal orders of multiple states in which the SWF and its subsidiaries had a significant presence. These included, inter alia, the United Kingdom (UK) and Italy. The European Union (EU) also implemented the measures at the supranational level. The UNSC then passed measures, in September 2011, to partially relax the freeze against

\footnotetext{
* Senior Lecturer, Macquarie Law School, Macquarie University, Sydney (Australia); Research Fellow, War Reparations Centre, Amsterdam Center for International Law, University of Amsterdam (The Netherlands); daley.birkett@mq.edu.au.

${ }^{* *}$ Research Associate, Centre for Comparative and Transnational Law, Faculty of Law, The Chinese University of Hong Kong, Hong Kong SAR (People's Republic of China); Research Affiliate, SovereigNet, The Fletcher School, Tufts University, Medford, MA (United States); dinisejko@cuhk.edu.hk.

The authors are grateful to Annalisa Ciampi, the anonymous peer reviewers, and Yaël Ronen and the Israel Law Review editorial team for their feedback on earlier drafts of this article.

${ }^{1}$ UNSC Res 1970 (26 February 2011), UN Doc S/RES/1970, para 17.

${ }^{2}$ UNSC Res 1973 (17 March 2011), UN Doc S/RES/1973, para 22, Annex II.
} 
the SWF. ${ }^{3}$ In 2012 Italy froze assets allegedly belonging to Gaddafi and two others at the request of the International Criminal Court (ICC), to which the UNSC had referred the situation in Libya in the same resolution as that in which it decided that states were to freeze the assets of the then Libyan leader. ${ }^{4}$ In fact, however, these assets belonged to the LIA and its subsidiary body, the Libyan Arab Foreign Investment Company (LAFICO).

This article explores how the LIA has sought to contest the application of the foregoing restrictions in the domestic courts of England and Wales and Italy, two jurisdictions in which the fund had made sizeable investments at the time at which the asset freezing measures were imposed (and in which it continues to hold substantial financial resources). In so doing, we aim to show that national courts have been sympathetic to the claims brought by the LIA, interpreting the easing of the measures in its favour. The novelty of the article, therefore, lies not only in our examination of asset-freezing measures directed at an entity (as opposed to an individual) but also in the comparative perspective adopted in respect of both the domestic jurisdictions (England and Wales, and Italy) and the legal regimes (the UNSC and ICC) under scrutiny.

The article is divided into four sections. First, we offer a brief introduction to the LIA, focusing particularly on how it was established to serve the people of Libya and its investment strategy in the UK and Italy. We also consider the events in Libya that led to the asset-freezing measures requested by the UNSC and the ICC (Section 2). We then examine the general question of how UNSC-requested asset-freezing measures are given supranational and domestic effect in the EU and UK legal orders, respectively, before reviewing the legal framework that governs the satisfaction of cooperation requests issued by the ICC in Italy. Additionally, we explore how the competent authorities in the UK and Italy (and, again only with respect to the former, the EU) sought to give domestic (and supranational) effect to the measures (Section 3). Our focus then shifts to how the LIA has attempted to contest the asset freeze at the UN, before the courts of England and Wales and in the Italian court system, demonstrating that success has been more forthcoming at the national than at the international level (Section 4). In the final part of the article we assert that domestic courts might, in certain cases, serve as additional fora in which individuals (and entities) might contest asset-freezing measures imposed against them by the responsible national authorities pursuant to a request by the UNSC and/or the ICC (Section 5).

\section{The Libyan Investment Authority}

This section examines the management structure and investment strategy of the LIA following its inception. We begin by analysing its establishment and investments made in the UK and Italy before turning to its listing by the UNSC as a result of its close association with the Gaddafi family and regime. In this regard we also discuss the disputes over the leadership of the fund, which have led to the perpetuation of sanctions against its assets despite Gaddafi's death in 2011.

\footnotetext{
${ }^{3}$ UNSC Res 2009 (16 September 2011), UN Doc S/RES/2009, paras 15-16.

${ }^{4}$ UNSC Res 1970 (n 1) para 4.
} 


\subsection{Establishment, InVestments and Governance}

Libyan financial entities were largely marginalised in international markets for over a decade, commencing in 1992, as a result of sanctions imposed by the UNSC following the destruction of Pan Am flight 103 over Lockerbie (Scotland), and the Union de Transports Aériens flight 772 over Niger. ${ }^{5}$ After the lifting of these restrictions in $2003,{ }^{6}$ the then unshackled bodies became far more active in investing in global markets, with the Libyan General People's Congress establishing a dedicated SWF in 2006. ${ }^{7}$ Under the LIA's 2010 Constitution, the fund has three principal goals: (i) the development and diversification of the national economy; (ii) to secure resources for future generations; and (iii) fiscal stability. ${ }^{8}$ In order to achieve these objectives, the LIA (and its subsidiaries) have made significant financial investments across a variety of industries, with most investments in Europe, the United States and Africa.

Chief among its European investment destinations are the UK and Italy. For example, in February 2011, shortly before its listing by the UNSC, the LIA owned a 3 per cent stake in Pearson Plc, which, until November 2015, owned The Financial Times. ${ }^{9}$ As of September 2010 the LIA also held equities in a number of prominent British companies, including Tesco Plc, Standard Chartered Plc and BP Plc, ${ }^{10}$ as well as a small stake ( 0.01 per cent) in the Royal Bank of Scotland Plc. ${ }^{11}$ At the same time, the LIA had also acquired a portfolio of luxury real estate in London $^{12}$ and was active in acquiring UK corporate and government bonds. ${ }^{13}$ Libyan financial entities have also made significant investments in Italian companies, a strategy that can be attributed to historical, economic and political considerations. ${ }^{14}$ For instance, in March 2011 (that is, the time the UNSC added the LIA to the sanctions list), it was reported that the LIA held a 2.5 per cent stake in the Italian financial group UniCredit SpA (with a

\footnotetext{
${ }^{5}$ UNSC Res 748 (31 March 1992), UN Doc S/RES/748, paras 4-6; UNSC Res 883 (11 November 1993), UN Doc $\mathrm{S} / \mathrm{RES} / 883$, para 3.

${ }^{6}$ UNSC Res 1506 (12 September 2003), UN Doc S/RES/1506, para 1.

${ }^{7}$ Law No 205 of 1374 DP (2006 AD) adopted by the General People's Congress (Libya).

${ }^{8}$ Law No 13 of 1378 DP (2010 AD) adopted by the General People's Congress (Libya), art 5.

9 James Hall, 'Libya's Corporate Connections: From Pearson to RBS', The Telegraph, 22 February 2011, https:// www.telegraph.co.uk/finance/businesslatestnews/8339450/Libyas-corporate-connections-from-Pearson-to-RBS. html.

${ }^{10} \mathrm{KPMG}$, 'Libyan Investment Authority Management Information Report', KPMG Audit and Assurance Reports, 30 September 2010, 13-14.

${ }^{11}$ Hall (n 9).

${ }^{12}$ Elena Moya, 'Libya Pours Millions into City Investments', The Guardian, 24 August 2009, https://www.theguardian.com/world/2009/aug/24/libya-pours-millions-into-city ('In July [2009], [the] LIA bought Portman House, on Oxford Street, for $£ 155 \mathrm{~m}$ from Land Securities. The $146,550 \mathrm{sq} \mathrm{ft}$ building hosts retailers, such as Boots and New Look, who pay an annual rent of $£ 11.5 \mathrm{~m}$. In December [2008], [the] LIA also purchased an office building at 14 Cornhill - opposite the Bank of England in the heart of the City and occupied by firms such as Aviva Investors - for £120m').

${ }^{13}$ KPMG (n 10) 15-18.

${ }^{14}$ Giorgio Sacerdoti and Pia Acconci, 'The Security Council's Asset Freeze against Gaddafi's Libya and Its Implementation in Italy' (2011) XXI Italian Yearbook of International Law 61, 77, fn 52 (observing that '[t]he shares of Libyan entities in major Italian listed companies which had been frozen had a market value of more than $€ 3$ billion at the time of the freeze').
} 
5 per cent stake in the same institution owned by the Central Bank of Libya, another entity listed by the UNSC at the same time, and for the same reason, ${ }^{15}$ as the LIA). ${ }^{16}$ Other Italian concerns in which the Libyan SWF and its subsidiaries had invested in 2011 included Juventus Football Club $\mathrm{SpA} ;{ }^{17}$ the aerospace, defence and security company Finmeccanica $\mathrm{SpA},{ }^{18}$ and the multinational energy corporation Eni SpA. ${ }^{19}$

The fund's governance structure is also enshrined in Libyan law and comprises: (i) a Board of Trustees, which consists of the Prime Minister (serving as Chairman); the Ministers for Economy, Finance, Planning, and Trade; the Governor of the Central Bank of Libya; and several experts; and (ii) a Board of Directors, whose six-strong membership is selected by the Board of Trustees. ${ }^{20}$ It also falls upon the Board of Trustees to nominate the CEO of the fund. ${ }^{21}$ As one might expect under such a framework, the LIA and its subsidiaries allegedly had close ties with the Gaddafi-controlled Libyan government at the time of their listing, with a number of regime loyalists (that is, at the time of the civil war if not since the establishment of the fund) reportedly playing prominent roles in the decision-making processes of the SWFs. ${ }^{22}$

\subsection{The UNSC-Requested Asset Freeze}

The origins of the Libyan civil war can be traced to protests in response to the arrest of human rights lawyer and activist, Fathi Tarbil. ${ }^{23}$ These protests, which started in Libya's second city, Benghazi, in February 2011, quickly escalated and spread across Libya, resulting in hundreds of deaths and injuries. ${ }^{24}$ Having expressed regret at the violence and loss of civilian lives in a press statement four days beforehand, ${ }^{25}$ on 26 February 2011, the UNSC unanimously adopted Resolution $1970,{ }^{26}$ in which it

\footnotetext{
${ }^{15}$ UNSC Res 1973 (n 2) Annex II.

${ }^{16}$ See, eg, 'Sanzioni economiche alla Libia Unicredit pronta a congelare i voti', La Repubblica, 8 March 2011, https://www.repubblica.it/economia/2011/03/08/news/sanzioni_economiche_alla_libia_le_ripercussioni_in_italia13346727; Sacerdoti and Acconci (n 14) 78.

17 ibid.

${ }^{18}$ ibid. The organisation rebranded in March 2016 as Leonardo SpA; see James Politi, 'Finmeccanica Turns to Leonardo for Renaissance', Financial Times, 16 March 2016, https://www.ft.com/content/84a87c78-eba1-11e5$888 \mathrm{e}-2 \mathrm{eadd} 5 \mathrm{fbc} 4 \mathrm{a} 4$.

${ }^{19}$ La Repubblica (n 16); Sacerdoti and Acconci (n 14) 78.

${ }^{20}$ Law No 13 of 1378 DP (n 8) art 6.

${ }^{21}$ ibid.

${ }^{22}$ See Lina Saigol and Cynthia O’Murchu, 'After Gaddafi: A Spent Force', Financial Times, 8 September 2011, https://www.ft.com/content/1b5e11b6-d4cb-11e0-a7ac-00144feab49a (reporting the alleged influence of Saif al-Islam Gaddafi, one of Muammar Gaddafi's sons, on LIA investment decisions).

${ }^{23}$ Dirk Vandewalle, A History of Modern Libya (2nd edn, Cambridge University Press 2012) 204.

${ }^{24}$ David D Kirkpatrick and Mona El-Naggar, 'Qaddafi's Son Warns of Civil War as Libyan Protests Widen', The New York Times, 20 February 2011, https://www.nytimes.com/2011/02/21/world/africa/21libya.html.

${ }^{25}$ UNSC, 'Security Council Press Statement on Libya' (22 February 2011), Press Release SC/10180.

${ }^{26}$ UNSC Res 1970 (n 1). UNSC Res 1970 also established a committee, namely the Security Council Committee Established pursuant to Resolution 1970 (2011) concerning Libya (Libya Sanctions Committee), to fulfil a number of tasks relating to the sanctions. These include monitoring their implementation, designating individuals subject to the measures and considering requests for exemption: UNSC Res 1970 (n 1) para 24.
} 
decided that all UN member states must freeze the assets of six individuals, namely the then Libyan leader, Muammar Gaddafi, and five of his children. ${ }^{27}$

On 17 March 2011, responding to an escalation in hostilities, the UN organ adopted a second resolution on the situation. UNSC Resolution 1973 extended the asset-freeze measures adopted in Resolution 1970, adding five entities to the list of natural and legal persons subject to the freeze mandated by Resolution $1970 .{ }^{28}$ Besides including the LIA - the first and, at the time of writing, the only time that the UNSC has designated a SWF on a sanctions list - the UNSC also listed the Central Bank of Libya, the Libyan Foreign Bank, the Libyan Africa Investment Portfolio, and the Libyan National Oil Corporation. ${ }^{29}$ The reason for listing these five entities, according to Resolution 1973, is that the each was '[u]nder [the] control of Muammar Gadhafi and his family, and [a] potential source of funding for his regime', ${ }^{30}$ which remained engaged in a bloody civil war with opposition forces at the time the measures were adopted.

UNSC Resolution 1973 had also established a 'No Fly Zone', that is, a ban on flights in the then Libyan Arab Jamahiriya airspace. ${ }^{31}$ This No Fly Zone - which was coupled with an authorisation to states 'to take all necessary measures ... to protect civilians and civilian populated areas under threat of attack in the Libyan Arab Jamahiriya ${ }^{32}$ - in practice helped to turn the tide of the war against the pro-Gaddafi forces in mid-August $2011 .{ }^{33}$ Sirte, one of the 'last strongholds of the regime', ${ }^{34}$ was taken by rebel troops on 20 October 2011 and Gaddafi was killed on the same day. ${ }^{35}$ In the meantime, the UNSC adopted a further resolution related to the asset freeze against the LIA. UNSC Resolution 2009, adopted on 16 September $2011,{ }^{36}$ represented an attempt to partially ease the restrictions placed upon the LIA and other entities by the measures adopted pursuant to Resolution $1973 .{ }^{37}$ With regard to the LIA's assets, the UNSC decided as follows: ${ }^{38}$

\footnotetext{
27 ibid para 17, Annex II (the five children listed alongside their father were Aisha Muammar Gaddafi, Hannibal Muammar Gaddafi, Khamis Muammar Gaddafi, Mutassim Gaddafi and Saif al-Islam Gaddafi).

${ }^{28}$ UNSC Res 1973 (n 2) para 22 ('decides ... that the individuals and entities listed in Annex II shall be subject to the asset freeze imposed in ... resolution 1970 (2011)').

${ }^{29}$ ibid Annex II.

30 ibid.

${ }^{31}$ ibid para 6.

32 ibid para 4.

${ }^{33}$ Vandewalle (n 23) 208. The No Fly Zone and authorisation related to the protection of civilians were both terminated by UNSC Res 2016 (27 October 2011), UN Doc S/RES/2016.

${ }^{34}$ Vandewalle (n 23) 208.

35 ibid.

${ }^{36}$ UNSC Res 2009 (n 3).

${ }^{37}$ The other entities to whom the partial easing applied were the Central Bank of Libya, the Libyan Arab Foreign Bank and the Libyan Africa Investment Portfolio. Additionally, the UNSC decided that the Libyan National Oil Corporation and Zueitina Oil Company were no longer subject to the asset freeze (and other) measures imposed under Resolution 1970 and Resolution 1973; see UNSC Res 2009 (n 3) para 14.

${ }^{38}$ UNSC Res 2009 (n 3) para 15 ('The five purposes for which exemption to the continued asset freeze could be sought, introduced by the UNSC in Resolution 2009, were as follows: (i) humanitarian needs; (ii) fuel, electricity and water for strictly civilian uses; (iii) resuming Libyan production and sale of hydrocarbons; (iv) establishing, operating, or strengthening institutions of civilian government and civilian public infrastructure; or (v) facilitating the resumption of banking sector operations, including to support or facilitate international trade with Libya'; see UNSC Res 2009 (n 3) para 16).
} 
(a) funds, other financial assets and economic resources outside of Libya ... that are frozen as of the date of this resolution pursuant to measures imposed in paragraph 17 of resolution 1970 (2011) or paragraph 19 of resolution 1973 (2011) shall remain frozen by States unless subject to an exemption ...;

(b) except as provided in (a), ... the LIA ... shall otherwise no longer be subject to the measures imposed in paragraphs 17 of resolution 1970 (2011), including that States are no longer required to ensure that any funds, financial assets or economic resources are prevented from being made available by their nationals or by any individuals or entities within their territories, to or for the benefit of these entities[.]

However, although interpreted by certain domestic courts for the benefit of the LIA, as will be demonstrated in Section 4, the partial easing of the freezing measures has failed to relieve the practical constraints imposed on the management of the Libyan SWF.

\subsection{The ICC-Requested Asset Freeze}

It was also in Resolution 1970 that the UNSC opted 'to refer the situation in the Libyan Arab Jamahiriya since 15 February 2011 to the Prosecutor of the International Criminal Court', ${ }^{39}$ a process pursuant to which the ICC Prosecutor swiftly opened an investigation into alleged crimes and, on 27 June 2011, successfully applied to the Pre-Trial Chamber for arrest warrants for Muammar Gaddafi, ${ }^{40}$ his son and assumed heir Saif al-Islam Gaddafi, ${ }^{41}$ and his Chief of Military Intelligence Abdullah al-Senussi. ${ }^{42}$ With the proceedings against Muammar Gaddafi having been terminated following his death in November 2011, the ICC Prosecutor explicitly confirmed to the UNSC that he had requested several states to freeze assets belonging to the two surviving accused persons in the following terms: ${ }^{43}$

The Office will also continue to search out the personal assets of Saif Al-Islam Gaddafi and Abdallah Al-Senussi for the potential benefit of the victims, through reparations awarded by the Court. Since the opening of the situation, the Office has been in contact with the UN Sanctions Committee, which is assisted by a Panel of Experts and with Interpol to coordinate its investigative efforts in relation to the assets of the suspects. The Court has sent at the end of September requests for assistance to Libya, State Parties, and five UN Security Council non-State Parties to identify, trace, seize and freeze all the personal assets belonging to the suspects. The Office strongly encourages the Security Council and States to assist the Court in identifying and isolating these assets.

\footnotetext{
${ }^{39}$ UNSC Res 1970 (n 1) para 4.

${ }^{40}$ ICC, Situation in the Libyan Arab Jamahiriya, Warrant of Arrest for Muammar Mohammed Abu Minyar Gaddafi, ICC-01/11-01/11-2, Pre-Trial Chamber, 27 June 2011.

${ }^{41}$ ICC, Situation in the Libyan Arab Jamahiriya, Warrant of Arrest for Saif Al-Islam Gaddafi, ICC-01/11-01/11-3, Pre-Trial Chamber, 27 June 2011.

${ }^{42}$ ICC, Situation in the Libyan Arab Jamahiriya, Warrant of Arrest for Abdullah Al-Senussi, ICC-01/11-01/11-4, Pre-Trial Chamber, 27 June 2011.

${ }^{43}$ ICC, Prosecutor's Statement to the United Nations Security Council on the Situation in Libya, pursuant to UNSCR 1970 (2011), 2 November 2011, para 13.
} 
As the Prosecutor's statement indicates, though the UNSC and ICC had each asked a number of states to freeze assets belonging to the same individuals, this is not to say that the measures serve precisely the same purpose(s). ${ }^{44}$ According to Giorgio Sacerdoti and Pia Acconci: ${ }^{45}$

The different purposes of the asset freeze by the [UN]SC and the seizure order by the ICC Prosecutor must be noted. The SC measures are aimed at preventing the targeted individuals of the Gaddafi regime to avail themselves of the funds and hide them, with the ultimate purpose that they be put at the disposal of the new legitimate Libyan government. The Prosecutor acts under the Rome Statute in order to preserve funds for the compensation of the victims.

To the latter, one could add further purposes, including the enforcement of orders of forfeiture or fines, if imposed upon conviction, and facilitating the arrest and surrender of the accused. ${ }^{46}$

\section{Implementing UNSC- AND ICC-Requested Asset Freezes at the DOMESTIC LEVEL}

UNSC resolutions requesting states to freeze the assets of those on sanctions lists are not selfexecuting but demand action from states to give effect to the measures at the domestic level. ${ }^{47}$ The same can be said of requests issued by the ICC for the freezing of accused persons' assets. Implementation can take place through legislative action on the supranational and/or domestic planes. The following section will examine - both in general terms and with specific reference to the asset freezes in relation to Libya - how the UK implements UN sanctions in its national legal order and how Italy gives domestic effect to requests for cooperation encompassing assetfreezing measures sent by the Court. ${ }^{48}$ First, however, because the UK was still an EU member state when it implemented the asset freeze ordered by the UNSC against individuals and entities in Libya, we will discuss briefly how UN sanctions are given effect in the EU legal order.

\footnotetext{
${ }^{44}$ Annalisa Ciampi, 'Security Council Targeted Sanctions and Human Rights' in Bardo Fassbender (ed), Securing Human Rights? Achievements and Challenges of the UN Security Council (Oxford University Press 2011) 98, 135-36; Larissa van den Herik, 'The Individualisation of Enforcement in International Law: Exploring the Interplay between United Nations Targeted Sanctions and International Criminal Proceedings' in Tiyanjana Maluwa, Max du Plessis and Dire Tladi (eds), The Pursuit of a Brave New World in International Law: Essays in Honour of John Dugard (Brill Nijhoff 2017) 234, 259-62; Paul Bentall, 'United Nations Targeted Sanctions and Other Policy Tools: Diplomacy, Legal, Use of Force' in Thomas J Biersteker, Sue E Eckert and Marcos Tourinho (eds), Targeted Sanctions: The Impacts and Effectiveness of United Nations Action (Cambridge University Press 2016) 79, 96-99; cf Marina Mancini, 'UN Sanctions Targeting Individuals and ICC Proceedings: How to Achieve a Mutually Reinforcing Interaction' in Natalino Ronzitti (ed), Coercive Diplomacy, Sanctions and International Law (Brill Nijhoff 2016) 228, 239-44.

${ }^{45}$ Sacerdoti and Acconci (n 14) fn 70.

${ }^{46}$ See William A Schabas, The International Criminal Court: A Commentary on the Rome Statute (2nd edn, Oxford University Press 2016) 1320.

${ }^{47}$ Vera Gowlland-Debbas, 'Implementing Sanctions Resolutions in Domestic Law' in Vera Gowlland-Debbas (ed), National Implementation of United Nations Sanctions: A Comparative Study (Martinus Nijhoff 2004) 33, 37.

${ }^{48}$ Italy's implementation of the UNSC asset-freezing measures against Libyan individuals and entities is discussed elsewhere: Sacerdoti and Acconci (n 14) 77-81.
} 


\subsection{THE EUROPEAN UNION}

It should be noted at the outset that the EU, unlike its member states, all of which are member states of the UN, is not subject to the direct obligation under Article 25 of the Charter of the United Nations (UN Charter) 'to accept and carry out the decisions of the Security Council'. ${ }^{49}$ Daniel Bethlehem expresses the following view: 'If the EU has an obligation to act at all in relation to such measures, it is a derivative obligation based on the obligation of individual EU Member States under the Charter in respect of UNSC decisions and the transfer of competence in respect of such matters from the Member States to the Community'. ${ }^{0}$ That said, the EU has nevertheless been granted the power to impose sanctions against states, non-state actors and both natural and legal persons by the Treaty on the Functioning of the European Union (TFEU) in the context of its Common Foreign and Security Policy (CFSP). ${ }^{51}$ According to Article 215 TFEU: ${ }^{52}$

1. Where a decision, adopted in accordance with Chapter 2 of Title V of the Treaty on European Union, provides for the interruption or reduction, in part or completely, of economic and financial relations with one or more third countries, the Council, acting by a qualified majority on a joint proposal from the High Representative of the Union for Foreign Affairs and Security Policy and the Commission, shall adopt the necessary measures. It shall inform the European Parliament thereof.

2. Where a decision adopted in accordance with Chapter 2 of Title V of the Treaty on European Union so provides, the Council may adopt restrictive measures under the procedure referred to in paragraph 1 against natural or legal persons and groups or non-State entities.

Panos Koutrakos categorises the internal process of adopting sanctions on the EU plane under this provision as 'a two-step procedure: first, the Council adopts a CFSP Decision in which it expresses its wish for relations with a third country to be interrupted or reduced; secondly, the Council adopts a Regulation in which it sets out in detail the rules governing the sanctions'. ${ }^{53}$ When imposing sanctions against individuals, entities or groups, rather than states - also known as 'targeted sanctions' ${ }^{54}$ - another legal basis for EU action is found in Article 75 TFEU. ${ }^{55}$

\footnotetext{
${ }^{49}$ Charter of the United Nations (entered into force 24 October 1945) 1 UNTS XVI (UN Charter) art 25. On the absence of any such 'international treaty obligation' on the part of the EU, see also Paola Mariani, 'The Implementation of UN Security Council Resolutions Imposing Economic Sanctions in the EU/EC Legal System: Interpillar Issues and Judicial Review' in Claudio Dordi (ed), The Absence of Direct Effect of WTO in the EC and in Other Countries (Giappichelli 2010) 187, 189.

${ }^{50}$ Daniel Bethlehem, 'The European Union' in Gowlland-Debbas (ed) (n 47) 123, 127 (emphasis in original).

${ }^{51}$ Consolidated Version of the Treaty on the Functioning of the European Union [2008] OJ C 115/47 (TFEU).

52 ibid art 215.

${ }^{53}$ Panos Koutrakos, EU International Relations Law (2nd edn, Hart 2015) 495, 504-08.

${ }^{54}$ See, eg, Biersteker, Eckert and Tourinho (eds) (n 44).

55 'Where necessary to achieve the objectives set out in Article 67, as regards preventing and combating terrorism and related activities, the European Parliament and the Council, acting by means of regulations in accordance with the ordinary legislative procedure, shall define a framework for administrative measures with regard to capital
} 


\subsection{United Kingdom}

Until 2020 the UK implemented UN sanctions in its legal order through domestic legislative action and EU law. ${ }^{56}$ As to the former, both primary legislation (statutes adopted by the UK Parliament) and delegated legislation, which includes statutory instruments made by Ministers deriving their authority to so act from primary legislation or by the Crown through Orders in Council, ${ }^{57}$ have been used to implement UN sanctions in UK law. Such Orders in Council can be made pursuant to the United Nations Act 1946, a piece of primary legislation designed to allow effect to be given in the UK legal order for certain provisions of the UN Charter. Section 1(1) of the United Nations Act 1946 provides as follows: ${ }^{58}$

If, under Article forty-one of the Charter ... (being the Article which relates to measures not involving the use of armed force) the [UNSC] call[s] upon His Majesty's Government in the United Kingdom to apply any measures to give effect to any decision of that Council, His Majesty may by Order in Council make such provision as appears to Him necessary or expedient for enabling those measures to be effectively applied, including (without prejudice to the generality of the preceding words) provision for the apprehension, trial and punishment of persons offending against the Order.

According to Sir Christopher Greenwood CMG QC, 'the necessity for the United Nations Act stems from the rule of [UK] law which precludes unincorporated treaties from being enforced in the [UK] courts'. ${ }^{59}$ As the UN Charter has not been implemented into UK law, it cannot be directly enforced before courts in the UK, but the UK is still bound to give effect to decisions of the UNSC in line with Article 25 of the UN Charter. ${ }^{60}$

Greenwood identifies a series of additional pieces of legislation used to give effect to UN sanctions in the UK legal order. These include the Import of Goods (Control) Order 1954 and the Export Control Act 2002, which regulate the import of goods into and export of goods from the UK. ${ }^{61}$ A final piece of legislation used to give effect to UN sanctions in the UK legal order, and potentially relevant for the subject-matter under examination in the present article, is the Emergency Laws (Re-enactments and Repeals) Act 1964, section 2(1) of which

movements and payments, such as the freezing of funds, financial assets or economic gains belonging to, or owned or held by, natural or legal persons, groups or non-State entities. The Council, on a proposal from the Commission, shall adopt measures to implement the framework .... The acts referred to in this Article shall include necessary provisions on legal safeguards': TFEU (n 51) art 75; see also Koutrakos (n 53) 495, 511-13.

${ }^{56}$ The UK withdrew from the EU at 23:00 GMT on Friday, 31 January 2020. The European Union (Withdrawal) Act 2018, s 1, provides for the repeal of the European Communities Act 1972 'on exit day'.

${ }^{57}$ See Statutory Instruments Act 1946, s 1 (UK).

${ }^{58}$ United Nations Act 1946, s 1(1) (UK).

${ }^{59}$ Christopher Greenwood CMG QC, 'United Kingdom' in Gowlland-Debbas (ed) (n 47) 581, 587. On the development of the 'doctrine of incorporation' in the case law of the courts of England and Wales, see also JG Collier, 'Is International Law Really Part of the Law of England?' (1989) 38 International \& Comparative Law Quarterly 924.

${ }^{60}$ UN Charter (n 49) art 25 ('The Members of the United Nations agree to accept and carry out the decisions of the Security Council in accordance with the present Charter').

${ }^{61}$ Greenwood (n 59) 588. 
permits the UK Treasury to freeze foreign assets in the UK under certain conditions. ${ }^{62}$ As Greenwood makes clear, however, these pieces of legislation, unlike the United Nations Act 1946, are not designed explicitly to implement UN sanctions in the UK, but have been used to do so. ${ }^{63}$

For as long as the UK was a member state of the EU, ${ }^{64} \mathrm{EU}$ law, more broadly, as well as in specific cases of giving effect to sanctions determined by the UNSC, was implemented in the UK through legislation passed pursuant to section 2(2) of the European Communities Act $1972 .{ }^{65}$ This legislation was, like legislation adopted pursuant to the United Nations Act 1946, enacted through Orders in Council, although it also took other forms, namely orders, rules, regulations and schemes. ${ }^{66}$

The UK implemented UNSC sanctions adopted in relation to Libya by way of an Order in Council, the Libya (Financial Sanctions) Order 2011, ${ }^{67}$ pursuant to the United Nations Act 1946. At the same time, because the UK was a member of the EU when the latter adopted Regulation 204/2011, the UK also gave effect to the relevant EU legislation through the Libya (Asset-Freezing) Regulations 2011 of 3 March 2011.68 This statutory instrument was drafted by the UK Treasury in accordance with section 2(2) of the European Communities Act 1972. The sanctions against the six named individuals decided upon by the UNSC in Resolution 1970 were implemented in the EU legal order through Regulation No 204/2011 of 2 March $2011,{ }^{69}$ which was later repealed and superseded by Regulation (EU) 2016/44 of 18 January $2016 .^{70}$ The LIA was added to the list of sanctioned entities through Regulation (EU) No 360/ $2011,{ }^{71}$ while the partial lifting of the sanctions was given effect in the EU legal order by Regulation (EU) No 965/2011. ${ }^{72}$ The freezing measures were therefore swiftly implemented

\footnotetext{
62 ibid 588-9. As Greenwood observes, '[s]ince the freezing of assets might also be an important part of economic sanctions, this provision also provides a basis for action to implement certain sanctions'.

${ }^{63}$ ibid 589. On such practice see also Hazel Fox and C Wickremasinghe, 'UK Implementation of UN Economic Sanctions' (1993) 42 International \& Comparative Law Quarterly 945, 955-64.

${ }^{64}$ See $\mathrm{n} 56$.

${ }^{65}$ European Communities Act 1972, s 2(2) (UK) provided, in relevant part, as follows: 'At any time after its passing Her Majesty may by Order in Council, and any designated Minister or department may by order, rules, regulations or scheme, make provision - (a) for the purpose of implementing any EU obligation of the United Kingdom, or enabling any such obligation to be implemented, or of enabling any rights enjoyed or to be enjoyed by the United Kingdom under or by virtue of the Treaties to be exercised; or (b) for the purpose of dealing with matters arising out of or related to any such obligation or rights'.

${ }^{66}$ ibid.

${ }^{67}$ Libya (Financial Sanctions) Order 2011, SI 2011/548 (UK).

${ }^{68}$ Libya (Asset-Freezing) Regulations 2011 SI 2011/605 (UK).

${ }^{69}$ Council Regulation (EU) 204/2011 of 2 March 2011 concerning Restrictive Measures in view of the Situation in Libya [2011] OJ L 58/1. Regulation 204/2011 was adopted in accordance with Council Decision 2011/137/CFSP of 28 February 2011 concerning Restrictive Measures in view of the Situation in Libya [2011] OJ L 58/53.

${ }^{70}$ Council Regulation (EU) 2016/44 of 18 January 2016 concerning Restrictive Measures in view of the Situation in Libya and repealing Regulation (EU) 204/2011 [2016] OJ L 12/1 (Regulation 2016/44).

${ }^{71}$ Council Implementing Regulation (EU) 360/2011 of 12 April 2011 implementing Article 16(1) and (2) of Regulation (EU) 204/2011 concerning Restrictive Measures in view of the Situation in Libya [2011] OJ L 100/12.

${ }^{72}$ Council Regulation (EU) 965/2011 of 28 September 2011 amending Regulation (EU) 204/2011 concerning Restrictive Measures in view of the Situation in Libya [2011] OJ L 253/8.
} 
by the responsible authorities in both the UK and the EU, thereby giving domestic and, in respect of the latter, supranational effect to the measures adopted by the UNSC.

\subsection{ITALY}

Italy gives domestic effect to its general obligation to cooperate with the $\mathrm{ICC}^{73}$ as well as its duty to 'ensure that there are procedures available under [its] national law for all of the forms of cooperation' listed in Part IX of the ICC Statute ${ }^{74}$ pursuant to Law 237 of 12 December 2012. Italy adopted this detailed piece of national implementing legislation more than 13 years after enacting legislation authorising ratification of the Court's constituent instrument. ${ }^{75}$ Article 1 of Law 237 of 12 December 2012 explicitly incorporates into the Italian legal order Italy's general obligation to cooperate with the ICC, ${ }^{76}$ while Article 2 stipulates that the task of handling such cooperation on Italy's behalf is the responsibility of the Minister of Justice. ${ }^{77}$

As far as the freezing of assets at the request of the ICC is concerned, Article 21 of Law 237 of 12 December 2012 provides, in relevant part: 'The Court of Appeal of Rome shall, at the request of the Attorney General at the same court, execute the confiscation of profits, property or assets ordered by the International Criminal Court' ${ }^{78}$

The remaining provisions regulate such issues as transmission of documents, offences against the administration of justice, and the enforcement of sentences of the ICC issued in Italy. Before the entry into force of this dedicated law, cooperation requests issued to Italy by the Court would have been processed together with requests for mutual legal assistance sent from other states, that is, under the relevant provisions of the Italian Code of Criminal Procedure. ${ }^{79}$

\footnotetext{
${ }^{73}$ Rome Statute of the International Criminal Court (entered into force 1 July 2002) 2187 UNTS 90 (ICC Statute) art 86 ('States Parties shall, in accordance with the provisions of this Statute, cooperate fully with the Court in its investigation and prosecution of crimes within the jurisdiction of the Court').

${ }^{74}$ ibid art 88. For discussion of Italy's obligation to implement (parts of) the ICC Statute see Marco Roscini, 'Great Expectations: The Implementation of the Rome Statute in Italy' (2007) 5 Journal of International Criminal Justice 493, 495-97.

${ }^{75}$ Legge 12 Iuglio 1999, n. 232 [Law n. 232 of 12 July 1999] (Italy), published in the Official Gazette, n. 167 of 19 July 1999. For discussion of some of the (at the time, prospective) obstacles to Italy's capacity to implement the ICC Statute, see Paolo Benvenuti, 'Italy, Implementation of the ICC Statute in National Legislation, Constitutional Aspects' in Claus Kress and Flavia Lattanzi (eds), The Rome Statute and Domestic Legal Orders Volume 1: General Aspects and Constitutional Issues (Nomos/Il Sirente 2000) 123.

${ }^{76}$ Legge 12 Dicembre 2012, n. 237 [Law n. 237 of 12 December 2012] (Italy), art 1 ('Lo Stato italiano coopera con la Corte penale internazionale conformemente alle disposizioni dello statuto della medesima Corte, reso esecutivo dalla legge 12 Iuglio 1999, n. 232, di seguito denominato «statuto», e della presente legge, nel rispetto dei principi fondamentali dell'ordinamento giuridico italiano' ['The Italian State shall cooperate with the International Criminal Court in accordance with the provisions of the Statute of the same Court, made enforceable by Law No 232 of 12 July 1999, hereinafter referred to as the 'Statute', and of this Law, in compliance with the fundamental principles of the Italian legal system']) (authors' translation).

77 ibid art 2.

${ }_{78} \mathrm{ibid}$ art 21(2) (authors' translation).

${ }^{79}$ Codice di Procedura Penale [Code of Criminal Procedure], arts 723-26ter (Italy).
} 
Although the ICC Prosecutor did not publicly name ${ }^{80}$ the states to which the Court sent requests for cooperation, it has since come to light that Italy was among the recipients. ${ }^{81}$ As Sacerdoti and Acconci keenly observe, because Italy's national implementing legislation had not entered into force at that time, the asset-freezing measures requested by the ICC must have been given effect in the Italian legal order in accordance with the Code of Criminal Procedure, the provisions of which regulate 'cooperation with foreign penal authorities' in general terms. ${ }^{82}$

\section{Fighting the Freezes}

Libyan officials and those purporting to represent the LIA have made a series of attempts to challenge the asset freezes at the international and domestic levels. The fund's success before the courts of England and Wales and in the Italian courts is marked when contrasted with the lack thereof when requesting relief from the restrictions on the international plane.

\subsection{At the International LeVel}

On 21 March 2016, the then Permanent Representative of Libya to the UN, Ibrahim Dabbashi, sent a letter addressed to the President of the UNSC. ${ }^{83}$ In this letter Mr Dabbashi appealed to the UNSC to revise Resolutions 1970, 1973 and 2009 (that is, those perpetuating the partial asset freeze) to allow the LIA 'to engage in fund management within the frozen accounts to prevent the further dissipation of LIA assets' ${ }^{84}$ The rationale behind Ambassador Dabbashi's request was clear: ${ }^{85}$

When the assets freeze was originally put in place, it was of course not intended as a punishment to Libya, but rather a protective measure to protect the assets against dissipation during the revolution and the transition after the fall of the Gaddafi regime. Yet the assets freeze is now having a very serious negative impact on the interests of the Libyan people. ... The LIA estimates that in 2014 alone, instead of increasing the value of its assets base, it had real losses of $\$ 721$ million. Furthermore, it lost an additional $\$ 1.6$ billion to $\$ 2.3$ billion in what would have been returns on investment if its assets had been properly invested in conservative investments with competitive interest rates.

Despite this, in our view, compelling and pragmatic appeal by the Libyan authorities, at the time of writing the majority of LIA assets remain frozen in accordance with Resolutions 1970, 1973

\footnotetext{
${ }^{80} \mathrm{cf}$ text to $\mathrm{n} 43$.

${ }^{81}$ Domenico Lusi and Carlo Marroni, 'Sequestrati i beni di Gheddafi in Italia', Il Sole 24 Ore, 29 March 2012, https://st.ilsole24ore.com/art/notizie/2012-03-28/sequestrati-beni-gheddafi-italia-225355.shtml.

${ }^{82}$ Sacerdoti and Acconci (n 14) fn 69.

83 'Letter dated 21 March 2016 from the Permanent Representative of Libya to the United Nations addressed to the President of the Security Council' (23 March 2016), UN Doc S/2016/275.

${ }^{84}$ ibid 1.

${ }^{85}$ ibid 1 .
} 
and 2009. This is because the LIA continues to be named on the list of sanctioned entities maintained by the Libya Sanctions Committee. ${ }^{86}$ This is also the case despite the fact that, in 2016, in acknowledging the letter sent by Ambassador Dabbashi, the UNSC: ${ }^{87}$

Reaffirm[ed] its intention to ensure that assets frozen pursuant to paragraph 17 of resolution 1970 (2011) shall at a later stage be made available to and for the benefit of the Libyan people and taking note of the letter ..., affirm[ed] the Security Council's readiness to consider changes, when appropriate, to the asset freeze at the request of the Government of National Accord[.]

Successive Panels of Experts established by Resolution 1973 have also acknowledged concerns at the loss in value of LIA assets caused by the continued asset freeze. In 2016, the Panels of Experts drew the attention of the UNSC to the fact that all investments made by the LIA frozen in 2011 had then matured and were being held in cash by financial institutions outside Libya. ${ }^{88}$ As a consequence, the Panel observed that '[c]ash deposits accrue little, if any, interest, nor earnings that could be achieved from investment'. ${ }^{89}$ Such 'rigidity of the ... sanctions regime' was also highlighted in the final report of the following Panels of Experts. ${ }^{90}$ This said, the Panel also noted that it could be problematic to revise the regime in view of the fund's divided management, referring to claims from two rival CEOs, one operating from the LIA office in La Valletta (Malta), and the other from the fund's Tripoli office. ${ }^{91}$ Subsequent Panels of Experts have been even more explicit in cautioning against relaxing the restrictions. For example, according to the Panel report of March 2021:92

The need to use an international consulting firm to provide reports to the Panel, the discrepancies between the consultant report and the overall report, and the inability of LIA to provide audited consolidated accounts are all indicative of an organization that does not have a properly established back office, an appropriate accounting department and adequate financial controls. As with the lack of investment policies, there is a clear risk to the Libyan people's money from any easing of the sanctions while this situation persists.

\footnotetext{
${ }^{86}$ At the time of writing, the 1970 Sanctions List was last updated on 25 October 2021; see UNSC, 'Sanctions List Materials', 25 October 2021, https://www.un.org/securitycouncil/sanctions/1970/materials.

${ }^{87}$ UNSC Res 2278 (31 March 2016), UN Doc S/RES/2278, para 11.

${ }^{88}$ Final Report of the Panel of Experts on Libya Established pursuant to Resolution 1973 (2011) (9 March 2016), UN Doc S/2016/209, para 255.

89 ibid.

${ }^{90}$ Final Report of the Panel of Experts on Libya Established pursuant to Resolution 1973 (2011) (1 June 2017), UN Doc S/2017/466, para 227.

${ }^{91}$ ibid paras 216-26. See also Hassan Bouhadiv Abdulmagid Breish [2016] EWHC 602 (High Court of England and Wales, QB). On the contested management of the LIA and its impact on the fund's governance, see also Dini Sejko and Daley J Birkett, 'When United Nations Sanctions Impact International Financial Governance: Lessons from the Libyan Sovereign Wealth Fund' (2018) 34 American University International Law Review 387, 398-405. ${ }_{92}$ Final Report of the Panel of Experts on Libya Established pursuant to Resolution 1973 (2011) (8 March 2021), UN Doc S/2021/229 (2021 Panel Report), para 163.
} 
The question therefore remains as to how best to safeguard 'the wealth of a nation'. ${ }^{93}$ On the one hand, to read reports in 2020 that the value of the LIA portfolio might have been worth $\$ 4.1$ billion more had the UNSC not subjected the fund to sanctions for almost a decade might reasonably indicate that an easing of the measures is (long) overdue. ${ }^{94}$ On the other hand, it could equally be argued that governance reform must precede any such steps in this direction, not least in view of the SWF's long-disputed leadership. ${ }^{95}$ This uncertainty, however, has not prevented officials claiming to act on the part of the LIA from bringing proceedings on behalf of the fund in national courts in order to ease the asset-freeze measures.

It is important to note that the individuals and entities on the 1970 Sanctions List have recourse to a delisting procedure. ${ }^{96}$ However, the LIA has failed to submit a delisting request despite having had the opportunity to do so since the Focal Point for Delisting was established by the UNSC in December 2006. ${ }^{97}$ In sum, the one notable challenge to the sanctions imposed with regard to the LIA assets made at the UN level by Ambassador Dabbashi failed to result in any alleviation thereof. The large part of the assets held by the LIA in March 2011 remain frozen pursuant to measures intended to avoid their abuse by the family of the then Libyan leader Muammar Gaddafi, whose regime was unseated following his death more than ten years ago. The limited success of the LIA in fighting the two freezes has instead come from challenging their implementation by states in domestic courts. As Antonios Tzanakopoulos observes, domestic laws implementing UNSC sanctions 'remain - at least in the first instance - open to challenge before domestic courts, much like any other domestic administrative act' ${ }^{98}$ It is these courts, the operation of which is much less constrained by international politics and its related bureaucratic procedures, that not only offer additional fora in which entities and individuals can challenge asset freezes requested by the UNSC or the ICC, but would also appear to provide petitioners with a greater chance of securing a favourable result.

\footnotetext{
${ }^{93}$ A phrase employed in Tim Eaton, 'Libya: Investing the Wealth of a Nation', Chatham House, 4 March 2021, https://chathamhouse.shorthandstories.com/libya-investing-wealth-of-nation.

${ }^{94}$ Tom Arnold, 'Libya Sovereign Fund to Ask U.N. for Freedom to Invest Billions', Reuters, 14 August 2020, https://www.reuters.com/article/uk-libya-swf-idUKKCN25A1FV; Dominic Dudley, 'Libyan Investment Authority Says UN Sanctions Have Cost It $\$ 4.1$ Billion to Date', Forbes, 17 December 2020, https://www.forbes.com/sites/dominicdudley/2020/12/17/libyan-investment-authority-says-un-sanctions-have-cost-it-41-billionto-date.

${ }^{95}$ See Eaton (n 93).

${ }^{96}$ For discussion of this procedure from a due process perspective see, eg, Jeremy Matam Farrall, United Nations Sanctions and the Rule of Law (Cambridge University Press 2007) 221-23.

${ }^{97}$ As of 29 October 2021 only four individuals listed by the Libya Sanctions Committee have submitted delisting requests to the Focal Point established to consider such requests: UNSC Focal Point for De-listing, 'De-listing Requests', 29 October 2021, https://www.un.org/securitycouncil/sanctions/delisting/de-listing-request-stats. The UNSC instituted the delisting procedure in UNSC Res 1739 (19 December 2006), UN Doc S/RES/1730.

${ }^{98}$ Antonios Tzanakopoulos, 'United Nations Sanctions in Domestic Courts: From Interpretation to Defiance in Abdelrazik v. Canada' (2010) 8 Journal of International Criminal Justice 249, 250; see also Antonios Tzanakopoulos, 'Domestic Court Reactions to UN Security Council Sanctions' in August Reinisch (ed), Challenging Acts of International Organizations before National Courts (Oxford University Press 2010) 56.
} 


\subsection{In the Courts of ENGland and Wales}

The application of the UN sanctions against the LIA in the UK legal order came to the fore in a case between the fund and Mr Glenn Maud, to whose company, Propinvest Group Ltd, the LIA had loaned 12.5 million euros, a sum which, with interest accrued, amounted to more than $£ 17.5$ million at the time of the proceedings. ${ }^{99}$ In short, the LIA sought to recoup this debt by issuing a statutory demand against Mr Maud. ${ }^{100}$ The dispute between the parties did not centre on any denial on the part of Mr Maud that he had entered into an agreement with the LIA and that his company had defaulted on the payment; on the contrary, he accepted that the payment was overdue and that he had insufficient funds to pay the debt. ${ }^{101}$ Rather, Mr Maud sought 'to set aside the demand on the grounds that any payment of the amount due would amount to a breach of the sanctions regime currently in place prohibiting people in certain circumstances from dealing with the LIA' ${ }^{102}$ At the heart of the dispute concerning the application of the UN sanctions to the guarantee was the meaning of the words 'funds and economic resources' used in Article 5 of Regulation 2016/44, in Annex VI of which the LIA was, and remains, listed: ${ }^{103}$

1. All funds and economic resources belonging to, owned, held or controlled by the natural or legal persons, entities and bodies listed in Annexes II and III shall be frozen.

2. No funds or economic resources shall be made available, directly or indirectly, to or for the benefit of the natural or legal persons, entities or bodies listed in Annexes II and III.

[...]

4. All funds and economic resources belonging to, or owned, held or controlled on 16 September 2011 by the entities listed in Annex VI and located outside Libya on that date, shall remain frozen.

Before the High Court of Justice, the LIA argued that the wording of Article 5(4) does not include the obligation on the part of Mr Maud under the guarantee, drawing a distinction between Articles 5(1) and 5(2), with the former constituting a 'freezing prohibition' and the latter a 'making available prohibition'. ${ }^{104}$ In this regard counsel for the LIA submitted that the guarantor's obligations should fall under the 'making available prohibition' and that, as the LIA is subject only to the 'limited freezing prohibition in Article 5(4), there is nothing now to stop Mr Maud paying out under the guarantee'. ${ }^{105}$ However, Rose $\mathrm{J}$ found in favour of Mr Maud, expressing the view that the words 'funds and resources' ought to be given the same meaning

\footnotetext{
${ }^{99}$ Glenn Maud v The Libyan Investment Authority [2015] EWHC 1625 (Ch), [1]; Libyan Investment Authority v Maud [2016] EWCA Civ 788, [2].

100 ibid.

${ }^{101}$ Glenn Maud v The Libyan Investment Authority (n 99) [3].

102 ibid.

${ }^{103}$ Regulation 2016/44 (n 70) art 5.

${ }^{104}$ Glenn Maud v The Libyan Investment Authority (n 99) [36].

105 ibid.
} 
throughout Article 5. ${ }^{106}$ With regard to the argument raised by the LIA, Rose J concluded that 'the payment by Mr Maud of the sums due under the guarantee is prohibited by article 5(4) of Regulation 204/2011'.107

The LIA appealed against the decision by Rose $\mathrm{J}$, and the Court of Appeal issued its judgment allowing the appeal on 27 July 2016. Although Moore-Bick, Longmore and Macur LJJ agreed with Rose $\mathrm{J}$ that the words 'funds and resources' must be given the same meaning throughout Regulation 2016/44, ${ }^{108}$ they disagreed with her finding that payment pursuant to the guarantee should consequently be prohibited by Article 5(4) of the legislation. According to Moore-Bick $\mathrm{LJ}$, 'the correct understanding of article 5(4) is that the payment of debts due under obligations such as the guarantee, in this case, does not involve dealing with the obligation but represents the provision of new or additional funds'. ${ }^{109}$ For that reason, because Article 5(4) of Regulation 2016/44 provides only for the continued freezing of already-frozen assets, payment under the guarantee would not contravene the sanctions measures in force against the LIA. Again, in the words of Moore-Bick LJ: ${ }^{110}$

There is little doubt that the successive EU Regulations were intended to reflect and give effect to the Security Council resolutions rather than to establish a parallel but independent regime of a potentially more extensive nature. [...] The relaxation of sanctions following the overthrow of Colonel Gaddafi's regime was intended to allow the LIA to deal with assets outside Libya acquired after 16 September 2011 and to allow it to obtain new assets free of sanctions. It would have been very surprising if the Security Council had intended at the same time to tighten the sanctions insofar as they applied to assets which remained frozen, and the terms of Resolution 2009 (2011) make it clear that it did not. In my view [Regulation 2016/44] must be construed with that in mind.

The Court of Appeal, therefore, adopted a rather expansive interpretation of the relevant UN sanctions measures as translated into EU law and the law of England and Wales. Had the Court of Appeal accepted the reasons articulated by the High Court, then the LIA would have had a much smaller portfolio of assets to manage from among those intended for its access by the partial easing measures adopted by the UNSC in Resolution 2009 (2011). In addition, as Rose $\mathrm{J}$ notes in her judgment, ${ }^{111}$ the provisions of Regulation 2016/44 must be applied across all EU member states. Given that the LIA was established to make investments for the benefit of the Libyan people, it is hoped that an equally broad interpretation might be afforded to the partial easing measures in other jurisdictions in which the fund opts to litigate. ${ }^{12}$ The following

\footnotetext{
106 ibid [43].

107 ibid [43].

${ }^{108}$ Libyan Investment Authority v Maud (n 99) [21].

109 ibid [19].

110 ibid [17].

${ }_{111}$ Glenn Maud v The Libyan Investment Authority (n 99) [47].

${ }^{112}$ While there has been UN sanctions-related litigation in Belgium, the Cayman Islands, Libya and the UK, this has largely concerned the management of LIA funds as opposed to challenges to the (terms of) the asset-freezing measures per se; see, eg, Eaton (n 93) (discussing cases involving Palladyne International Asset Management and Euroclear, respectively).
} 
section will analyse the success of the LIA in the domestic courts of one such EU jurisdiction, Italy, but not in respect of asset-freezing measures requested by the UNSC. Instead, the focus rests on a successful challenge to an ICC-requested asset freeze.

\subsection{Before the Italian Courts}

It was pursuant to Article 666 of the Italian Code of Criminal Procedure that the LIA (through its legal representative) appealed against the freezing of a broad portfolio of assets by the responsible Italian authorities (the Guardia di Finanza, a branch of the Ministry of Economy and Finance) at the request of the ICC. ${ }^{113}$ In short, the LIA's appeal stemmed from its claim that the frozen assets did not actually belong to members of the Gaddafi family (including Muammar Gaddafi and Saif al-Islam Gaddafi, both of whom had been subject to arrest warrants issued by the ICC) or Abdullah al-Senussi. Rather, the LIA claimed that the frozen assets, in fact, did belong to the LIA and its subsidiary, LAFICO. ${ }^{114}$ The assets that formed the subject of this appeal included property in the Italian capital of Rome, shares in Juventus Football Club SpA, Finmeccanica SpA, UniCredit SpA, Eni SpA, the vehicle manufacturing company Fiat SpA and land in Pantelleria, an island situated in the Mediterranean Sea between Sicily and Tunisia. ${ }^{115}$ The LIA specifically alleged violations of the right to property of persons outside the criminal proceedings, the principle of state sovereignty, and the ICC Statute in support of its request that the freezing orders issued in respect of the foregoing assets between 22 March 2012 and 28 March 2012 be declared null and void. ${ }^{116}$ More precisely, the LIA argued that the measures taken by the Italian authorities were ultra vires the ICC Statute because there had not yet been a conviction which, in its opinion, is a requirement of Article 75(4) of the Court's constituent instrument. ${ }^{117}$ In other words, the LIA argued that: ${ }^{118}$

Measures of a preventive nature cannot be invoked in the instant case because of the content of Art. 57 of the [ICC] Statute, which refers to cooperation with reference to the preservation of evidence and the protection of witnesses.

Article 57(3)(e) of the ICC Statute empowers the Court's Pre-Trial Chamber to request states parties to 'take protective measures for the purpose of forfeiture, in particular for the ultimate benefit of victims', ${ }^{119}$ but only after 'a warrant of arrest or a summons has been issued'. ${ }^{120}$ In contrast,

\footnotetext{
${ }^{113}$ Corte di Appello di Roma [Rome Court of Appeal], Sezione Quarta Penale, N4/12 RGIE, 23 July 2012, para 1 (Italy).

114 ibid [2] ('alla fine del mese di marzo 2012, resa esecutiva la rogatoria in questione, la Guardia di Finanza aveva eseguito una serie di sequestri su beni asseritamene di proprietà di Gheddafi e della sua famiglia, mentre detti beni, in realtà, appartengono alla LIA e alla LAFICO').

115 ibid [2]-[3].

116 ibid [3]-[5].

117 ibid [4]; ICC Statute (n 73) art 75(4).

118 ibid (authors' translation).

${ }^{119}$ ICC Statute (n 73) art 57(3)(e).

120 ibid.
} 
Article 75(4) of the ICC Statute empowers the Court to determine whether measures under Article 93(1) thereof ought to be taken in order to give effect to an order for reparations to victims (only) 'after a person is convicted of a crime within the jurisdiction of the Court'. ${ }^{121}$ In turn, Article 93(1) of the ICC Statute requires states parties to provide the ICC with various forms of cooperation. These include assistance as regards 'identification, tracing and freezing or seizure of proceeds, property and assets and instrumentalities of crimes for the purpose of eventual forfeiture, without prejudice to the rights of bona fide third parties'. ${ }^{122}$

Turning to the Italian court's judgment, the bench noted that the ICC requested Italy's cooperation pursuant to Article 57(3)(e) of the ICC Statute - that is, the provision authorising the Court to request pre-trial 'protective measures for the purpose of forfeiture' ${ }^{\prime 23}$ - a request dated 26 October $2011^{124}$ and deemed enforceable in Italy on 21 February $2012 .{ }^{125}$ The Rome Court of Appeal also observed that the ICC, in its cooperation request, expressly delimited the object of the seizure to movable and immovable property, bank accounts, and shares belonging to or under the (in)direct control of the accused persons, or held by companies or bodies (in)directly owned or controlled thereby, without prejudice to the rights of bona fide third parties. ${ }^{126}$

What is more, according to the Italian court, the ICC also expressly noted its desire that any freezing measures implemented at its request should not interfere with the UNSC-ordered asset freeze 'to ensure that those assets that do not belong to or are not controlled by the suspects are made available and used for the benefit of the Libyan population'. ${ }^{127}$ This appears to be a pragmatic inclusion. First, it acknowledges the supremacy of states' obligations stemming from the UN Charter compared with other treaties, including the ICC Statute. ${ }^{128}$ Second, it recognises that Libya's wider population, beyond potential 'victims' (as defined at the ICC) ${ }^{129}$ of the crimes under the jurisdiction of the Court of which the (at the time, three) accused persons might be convicted, also has a valid claim to the assets under the control of those on the sanctions list.

Finally, the Rome Court of Appeal concluded that "the assets seized from the "LIA" ... cannot be included among those mentioned in the request of the International Criminal Court, since they cannot be traced back to the person against whom the [ICC] intends to proceed' ${ }^{130}$ In so doing, the Rome court attempted to guarantee that the rights of one bona fide third party, namely the LIA, were protected at the domestic level and, by extension, the international level. In other

\footnotetext{
${ }^{121}$ ibid art 75(4).

122 ibid art 93(1)(k).

${ }^{123} \mathrm{ibid}$ art 57(3)(e).

${ }^{124}$ Rome Court of Appeal (n 113) [5].

125 ibid [6].

126 ibid [6]-[7].

127 ibid [7] (authors' translation).

${ }^{128}$ UN Charter (n 49) art 103 ('In the event of a conflict between the obligations of the Members of the United Nations under the present Charter and their obligations under any other international agreement, their obligations under the present Charter shall prevail').

${ }^{129}$ ICC, Rules of Procedure and Evidence, UN Doc ICC-ASP/1/3 (ICC RPE), rule 85 (defines 'victims', whether natural or legal persons, according to the 'harm' they have suffered). It is only 'victims' in the ICC Statute system that are entitled to reparations in the event that the accused is ultimately convicted: ICC Statute (n 73) art 75(2). ${ }^{130}$ Rome Court of Appeal (n 113) para 7 (authors' translation).
} 
words, by terminating Italy's measures giving domestic effect to the Court's request for cooperation (at least in part), ${ }^{131}$ the ICC request no longer operated to the detriment of those (in this case, legal) persons against whom the restrictions were not directed. ${ }^{132}$

Why might this situation have arisen? Rule 99(2) of the ICC Rules of Procedure and Evidence (ICC RPE) explicitly provides that the Court need not provide notice of its request for the imposition of pre-trial protective measures 'unless the Court determines ... that notification could not jeopardize the effectiveness of the measures requested'. ${ }^{133}$ Where no notice is given, it falls to the ICC Registrar to notify the person(s) against whom the execution of the measures is requested as well as other 'interested persons' who are then invited 'to make observations as to whether the order should be revoked or otherwise modified'. ${ }^{134}$ This approach can be contrasted with that taken in respect of post-conviction forfeiture measures, which are governed in part by Rule 147(2) of the ICC RPE: 'If before or during the hearing, a Chamber becomes aware of any bona fide third party who appears to have an interest in relevant proceeds, property or assets, it shall give notice to that third party'. ${ }^{135}$

Although binding only upon the parties, with Italian court decisions not enjoying stare decisis in a formal sense, ${ }^{136}$ not only did the judgment of the Rome Court of Appeal bring an end to the impugned measures but, like the decision of Moore-Bick, Longmore and Macur LJJ in England and Wales, it might constitute relevant guidance for other domestic courts when faced with related claims in the future. ${ }^{137}$ When targeted by asset-freezing measures, individuals are disposed to conceal their assets by transferring them to third parties; but when the latter are bona fide, their interests must be protected under the terms of the ICC Statute. This article has aimed to show that the decision of the Rome Court of Appeal does exactly that.

\section{CONCLUSION}

In this article we have examined the interpretation by domestic courts of asset freezes requested by the UNSC and ICC through the lens of the LIA's experience in the UK and Italy, jurisdictions in which the SWF has made sizeable investments. In so doing, we have sought to demonstrate

\footnotetext{
${ }^{131}$ The Rome Court of Appeal terminated only the measures taken in respect of the shares in Eni SpA; those in Finmeccanica SpA and UniCredit SpA, the ownership of which remained contested, are to be addressed in a subsequent hearing: ibid [8].

${ }^{132}$ This might, however, raise an issue in terms of Italy's international legal responsibility for partially failing to execute the Court's request for cooperation, a question that falls outside the scope of the present article.

${ }^{133}$ ICC RPE (n 129) rule 99(2).

134 ibid rule $99(3)$.

135 ibid rule 147(2); ibid rule 147(3) further provides, in relevant part, that 'any bona fide third party with an interest in the relevant proceeds, property or assets may submit evidence relevant to the issue'.

${ }^{136}$ On the development 'a general expectation that precedents be followed', see Laura Baccaglini, Gabriella Di Paolo and Fulvio Cortese, 'Judicial Precedent in the Italian Legal System: A Shift Toward a Stare Decisis Model?', Stanford Law School China Guiding Cases Project, Commentary No 19, 2017.

${ }^{137}$ For example, the 2016 Court of Appeal decision in Libyan Investment Authority v Maud (n 99) could serve as (very) persuasive guidance, should courts in the Cayman Islands (or, indeed, other common law jurisdictions) be asked to adjudicate similar questions of law.
} 
that the use of national courts as fora in which the execution of such measures can be contested might be an effective, albeit cumbersome, strategy for the SWF to embrace in order to reclaim full control over the assets it was entrusted to administer on behalf of the Libyan people. The case for the adoption of such a strategy is made even stronger when considered in view of the difficulties encountered by the LIA at the UN level in seeking to restore its access to frozen accounts in order to act to prevent further losses to assets under its management. Because all UN member states are bound to give domestic effect to sanctions requested by the UNSC, and with EU regulations implementing such measures having direct effect in the legal orders of all EU member states, the LIA should be encouraged by the approach taken by the Court of Appeal in England and Wales. Indeed, the reasoning of Moore-Bick, Longmore and Macur LJJ could serve as persuasive, albeit not legally binding, guidance for other national courts, both within and outside the EU, in which the LIA could challenge the ongoing asset freeze.

As far as the decision of the Rome Court of Appeal is concerned, the article has shown that domestic courts represent valuable fora in which entities and, it is contended, individuals can seek to enforce some of the legal protections to which they are entitled under international law and the law of the state(s) implementing the restrictions when subjected to ICC-requested asset freezes. In other words, national courts constitute a layer of protection in addition to that offered before the ICC (or the UNSC) itself, supranational courts and human rights courts. 